\title{
The Different Pattern of Food Consumption between Local Farmers and Transmigrant Farmers in the Border Area of Papua, Indonesia
}

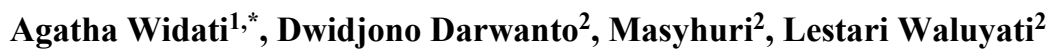 \\ ${ }^{1}$ Faculty of Agriculture, Universitas Papua, Jl. Gunung Salju Amban Manokwari Papua Barat. 98314, West Papua, Indonesia \\ ${ }^{2}$ Faculty of Agriculture, Universitas Gadjah Mada, Jl. Flora, Bulaksumur, Caturtunggal, Depok, Sleman, Yogyakarta, Indonesia \\ *Corresponding author: agathawidati@yahoo.co.id
}

Received April 17, 2019; Revised May 25, 2019; Accepted July 11, 2019

\begin{abstract}
As a component in the food and nutrition system, which determined by the quantity and quality of food, food consumption is an important priority to improve the quality of human resources. This study aims to determine the food consumption patterns of farmer households and the difference of its pattern between local and transmigrant farmer households in the border area of Papua. The study was conducted in four regencies in the northern part of Papua in adjacent to the Papua New Guinea (PNG) by involving a total number of 160 households, which consist of 80 local and 80 transmigrant farmer households. To measure the food consumption pattern, the researcher used the food consumption list and a food consumption analysis software developed by the Indonesian Food Security Agency in 2013. The contribution of food energy measured by the Energy Adequacy Rate (AKE) and Protein Adequacy Rate (AKP). The independent $t$-test was used to compare the food consumption pattern between local and transmigrant farmer households using statistical software, SPSS 16.0 version. The analysis reveals that the AKE and AKP of farmer households are below the recommended standard. The energy (protein) consumption of local farmer households is greater (lower) than the energy consumption of the transmigrant farmer households. The analysis of independent sample t-tests indicates that the average of energy and protein consumption of local farmers differed significantly from the average of energy and protein consumption of transmigrant farmers in the border area of Papua.
\end{abstract}

Keywords: $A K E, A K P$, food consumption, local farmers, transmigrant farmers

Cite This Article: Agatha Widati, Dwidjono Darwanto, Masyhuri, and Lestari Waluyati, "The Different Pattern of Food Consumption between Local Farmers and Transmigrant Farmers in the Border Area of Papua, Indonesia." Journal of Food and Nutrition Research, vol. 7, no. 7 (2019): 506-513. doi: 10.12691/jfnr-7-7-4.

\section{Introduction}

As one of the basic human needs besides clothing and shelter, food consumption is vital for human survival. According to [1], food is an important component of society, not only as a source of nutrition but also as a central part of everyday life. The Government Regulation number 68 of 2002 defines food as everything derived from biological sources and water, be it is processed or is not processed, which is intended as food and drink for humans, including food additives, food raw materials and other materials used in the preparation process, food processing and or the making of food or drinks. [2] stated that food is different from other commodities on the market in that it is explicitly and intrinsically linked to human existence.

Food consumption is one component in the food system [3]. Sudiaoetomo say that the level of food consumption is determined by the quality and quantity of the food serving. The quality of the food serving is indicated by the nutrient fulfillment of the body needs, while the quantity is shown by the ratio between nutrient fulfillment and nutrient requirement of the body. If the composition of the food serving meets the body needs, both in terms of quality and quantity, the body will receive the best nutritional health conditions [4]. On this account, the quality and quantity of food consumption are largely determined by food production and distribution as well as other factors.

Good fulfillment of food quality will improve the quality of human resources [5]. Good nutrition plays an important role in the optimal growth, development, health and well-being of individuals in all stages of life [2]. Nutrition is a fundamental pillar of human life, health and development across the entire life span [6]. Fulfillment of food is highly dependent on the agricultural sector, as the main sector of food providers. The availability of sufficient food will support the fulfillment of food consumption of the population. Teklu and Johnson as quoted by Nurfarma stated that the development of food availability, nutritional knowledge of the community, social-cultural condition, economics, and environmental condition are some of the factors to shape the consumption patterns of a society. Various empirical studies of food 
consumption patterns in Indonesia show that the performance of food consumption patterns varies according to regional type, season and socio economic characteristics [7].

The Papua Province is one of the provinces in Indonesia which bordered by Papua New Guinea. Interestingly, the agricultural system in Papua is quite different from the agricultural system of other regions in Indonesia. The agricultural sector in Papua is mainly driven by local and transmigrant farmers. Local farmers are indigenously born Papuan farmers who seek for subsistence agriculture, although some of them may still apply shifting cultivation. As [8] stated, the indigenous Papuan farmers tend to conduct subsistence farming with shifting cultivation. On the contrary, transmigrant farmers are non-native Papuan farmers, who come to live in Papua because of the transmigration program. Most of the transmigrant farmers conduct their farming more intensively and permanently. These two types of farmers also cultivate different types of food crops according to the preference. Local farmers prefer to cultivate cassava, secondary crops, and vegetables, while transmigrant farmers mostly cultivate rice, secondary crops, and vegetables.

Recently, the agricultural sector of Papua has considerable development, especially for food crops. This is apparent from the essential contribution of the agricultural sector to Papua's economic development as shown in 2014, the agriculture, forestry and fisheries sector contributed $14.11 \%$ to Papua's Gross Regional Domestic Product (GRDP). The contribution of the food crop sector to Papua's GRDP, on the basis of the current prices in 2014, was 3.22\%, showing an increase of $7.36 \%$ as compared to that in 2013 which was $3.08 \%$. Similarly, it is noteworthy that from $2012-2014$, there has been an increase in food crop production. Rice production made a leap by $41.98 \%$, corn had a marked increase of $13.93 \%$, sweet potato rose significantly to $19.36 \%$, and cassava soared to $24.08 \%$ [9]. In addition to these food crops, there are also sago, the forest plants used by indigenous Papuans as a staple food source of carbohydrates. In 2012-2014, sago production increased by $484.68 \%$ [9].

The city of Jayapura and Keerom Regency are two of the five regencies in the Papua Province, which adjacent to Papua New Guinea. The two regions were chosen as the regional representatives in this study because they are located in the northern part of the Papua and PNG borders, which are easily accessible from the provincial capital of Papua because these two regencies can be reached by land transportation, while other regencies bordering PNG cannot be reached by land transportation. In addition, based on the 2015 map of food security and food vulnerability in Indonesia, Jayapura and Keerom are included in the regencies with the prioritized vulnerability at level 1 and 2 as seen from the composite index of food security.

The total population in Jayapura and Keerom Regency in 2014 was 275,694 people and 53,002 people, respectively. Meanwhile, in 2010, the population of the two regencies was 256,705 people and 48,536 people respectively, with a population growth rate per year respectively at $3.6 \%$ and $2.22 \%$ [9]. The data reveal the constantly increasing population in Jayapura and Keerom Regency. An increase in population will be positively associated with an increase in consumption, especially the amount of food consumption. Given the geographical condition of Jayapura City and Keerom Regency, it is apparent that the two regencies have sufficient natural resource potential for agricultural development, which relatively ensures food availability. On a macro level, the level of energy availability for consumption by the population in 2012 in the Papua Province is 2,797 kilos of calories/capita/day [10], which means that this availability exceeds the national standard, where WNPG VIII 2012 recommends Adequacy Numbers Energy (AKE) of 2,400 kilos of calories/capita/day.

Some potential food commodities in this area include rice, sweet potatoes, corn, sago, bananas, beans, vegetables, livestock, and fish products. In some locations, food crop farming in Jayapura and Keerom Regency conducted by local farmers is still carried out with a traditional system and thus resulting in a low level of productivity. However, some developing agricultural areas especially the transmigration areas have performed food crops and horticulture cultivation more intensively using modern cultivation technology. This farming system has fostered the food crop and horticulture sub-sectors to become the main contributors to the economy of the agricultural sector and the economy of the regencies.

The location of Jayapura and Keerom Regency in the border area does not rule out the possibility of food distribution in and out of the region. This will affect food availability and will further affect the food consumption of the community. Based on the given background and problem formulation, the researcher formulated the following research questions: 1) How is the food consumption pattern of farmer households in the border area of Papua? 2) Are there any differences between the food consumption pattern of local and transmigrant farmer households in the border area of Papua? This research comes up with the following objectives: 1) To know the food consumption patterns of households in the northern region of the Papua border, and 2) To know the different pattern of food consumption between local farmers and transmigrant farmers' households in the northern region of the Papuaborder.

\section{Methods}

This study used a basic analytical descriptive method by way of survey techniques using a prepared questionnaire. Jayapura City and Keerom Regency were chosen as the research locations with the consideration that these two regencies were easily accessible by land transportation, their farming land was relatively closer to the border area, and the farmers normally cultivated cassava, rice, corn, sago, fruits, and vegetables. Furthermore, four regions of the two regencies adjacent to PNG were selected as the research locations. The sample in the first stage was determined purposively, by determining the farmer households to be a household group of local farmers and transmigrant farmer household groups. Local farmer households represent farmers who do not grow rice, while transmigrant households represent farmers who grow rice. Furthermore, the sampling for each group was carried out by simple random sampling consisting of 80 households, and totally amounting to 160 households. 
The analysis of the food consumption patterns of farmer households was carried out in several stages. The first stage aims to find out the frequency of meals and the types of food consumption using the $2 \times 24$ hour recall method. The second stage is to measure the consumption of real energy and household protein. The calculation of the number of energy and protein adequacy used the List of Food Composition (DKBM) with food consumption analysis software developed by the Indonesian Food Security Agency in 2013. The contribution of energy consumption for each food group was calculated based on Figures of Energy Adequacy (AKE) consumed, namely 2,150 calories/capita/day, and Protein Adequacy Rate (AKP) of 57 calories/capita/day. Meanwhile, the adequacy of energy availability is calculated based on AKE of 2,400 calories/capita/day and AKP of 62 calories/capita/day (Widyakarya National Food and Nutrition X, 2012). If the AKE percent value is more than $80 \%$, it is said to be sufficient for food, whereas the AKE percent value under $80 \%$ is said to be insufficient food. The AKP percentage of more than $80 \%$ is said to be sufficient for protein, whereas the AKP percentage under $80 \%$ is said to be insufficient of protein. AKE of more than $80 \%$ is said to be sufficient food to be used in measuring food security by Jonsson and Tolle [11]. Independent sample t-test was used to see the difference between food consumption of local farmers' households and transmigrant farmers' household, using SPSS software of 16.0 version.

\section{Results}

\subsection{Characteristics of Farmers' Households}

Characteristics of Farmers' Households in the Papua border area are seen from the average age of the head of the family, level of education, number of family members, area of land owned, and area of land cultivated.

Table 1. Characteristics of farmer's households in the Papua border area

\begin{tabular}{lcc}
\hline Characteristics & $\begin{array}{c}\text { Average } \\
\text { Local Farmers }\end{array}$ & $\begin{array}{c}\text { Transmigrant } \\
\text { Farmers }\end{array}$ \\
\hline $\begin{array}{l}\text { Age of the head of the family } \\
\text { (Year) }\end{array}$ & 40,32 & 44,38 \\
$\begin{array}{l}\text { Education level of the head of } \\
\text { the family }\end{array}$ & SMP $^{1}$ & SMA $^{2}$ \\
$\begin{array}{l}\text { Education level of the mother } \\
\text { Number of family members }\end{array}$ & SMP & SMP \\
(People) & 4 & 3 \\
Owned land area (ha) & 1,14 & 1,67 \\
\hline $\begin{array}{l}\text { Source: Primary Data 2017 } \\
1 \text { MiddleSchool } 2 \text { HighSchool }\end{array}$ & & \\
\hline
\end{tabular}

Table 1 pinpoints that overall, most of the head of the family of the transmigrant farmer households have a higher age and education level than that of the local farmer households. Moreover, the transmigrant farmer household also has a wider area of land owned and cultivated than that of local farmer households, whereas local farmer households have a higher average number of family members than that of transmigrant farmer households. The average age of the heads of households of local farmers and transmigrants is of productive age. Some studies also found that the age of farmers in Indonesia has a productive age $[12,13,14]$. This is in line with the study by [8] revealing that the land area managed by Papuan farmers was relatively smaller than non-Papuan farmers. On this account, [15] classified paddy farmers in Merauke Regency with an area of cultivated land of $0.5-1.49$ ha as smallholder farmers. Based on this classification, it is possible to classify the local farmers and migrants in the border area as smallholder farmers because they cultivated an area of land of less than 1.5 ha.

\subsection{Level of Participation of Farmer's Household Food Consumption}

This rate is calculated based on the proportion of households that consume certain types of food to the total household population observed. This type of food consists of food containing carbohydrates, most of which are staple foods, protein (animal and vegetable), fat, and vitamins/minerals. The results of the calculation of the participation level of food consumption of farmer households in the border area with carbohydrate as the main food sources are presented in Table 2.

In addition to carbohydrate food sources, the level of food consumption participation is also indicated by the level of food consumption participation of protein sources, both animal protein, and vegetable protein, as presented in Table 3.

In addition to obtaining protein from animal food, the farmer households in the border area also derive their protein from vegetable food. Their vegetable protein source is derived food from legumes. The level of participation in the consumption of vegetable protein sources is presented in Table 4.

Participation in the consumption of fat food sources, protein and vitamins is presented in Table 5 and Table 6.

\subsection{Consumption of Energy and Protein of Farmers' Households in the Border Area}

Household food consumption indicates the amount of calorie intake and protein consumed by farmer households. The average food energy consumption of farmers in the border area is presented in Table 7.

In line with AKE, the Protein Adequacy Rate (AKP) of farmer households in the border area is also still lower than the recommended AKP based on the 2012 WNPG X of 57 calories/capita/day. Farmers in the border area merely have protein consumption at $84.03 \%$ of the recommended AKP. Table 8 illustrates more details about the data.

\subsection{Desirable Dietary Pattern (PPH)}

The Desirable Dietary Pattern (PPH) is a composition of food diversity based on the contribution of energy from the main food groups at the level of availability and food consumption. PPH scores reflect the nutritional quality of food consumption, while the diversity level of PPH food consumption can be used as a reference for setting targets in planning and evaluating the supply of food production in particular. According to Hardinsyah, based on an analysis 
of nutritional quality of food consumption (MGP), the PPH score is categorized into very poor $(<55 \%)$, poor $(55-69 \%)$, sufficient (70-84\%) and good ( $\geq 85 \%)$ [16].

To see whether the food consumption pattern of local farmers household is different from the food consumption pattern of transmigrant farmers' households in the border area, the researcher conducted a statistic test using two independent sample t-tests. The average energy consumption and protein of farmer households are presented in Table 10.

The result of the independent sample t-test conducted to statistically compare the energy consumption and protein consumption of local farmer households and transmigrant farmers' household is presented in Table 10.

Table 2. Level of Participation in Consumption of Carbohydrate Food Sources of Farmer Households in the Border Area

\begin{tabular}{|c|c|c|c|c|c|c|}
\hline \multirow[t]{2}{*}{ Type of Food } & \multicolumn{3}{|c|}{ Foof Quantity kkal/kap/hr } & \multicolumn{3}{|c|}{ Energy Contribution (\%) } \\
\hline & Local & Transmigrant & Local+Transmigrant & Local & Transmigrant & Local+Transmigrant \\
\hline Rice & 931,53 & $1.088,13$ & 931,53 & 73,62 & 84,19 & 73,62 \\
\hline Corn & 11,65 & 15,49 & 11,65 & 0,92 & 1,20 & 0,92 \\
\hline Flour & 31,46 & 42,96 & 31,46 & 2,49 & 3,32 & 2,49 \\
\hline Cassava & 92,94 & 40,34 & 92,94 & 7,34 & 3,12 & 7,34 \\
\hline Sweet Potato & 94,93 & 52,38 & 94,93 & 7,50 & 4,05 & 7,50 \\
\hline Sago & 78,34 & 45,72 & 78,34 & 6,19 & 3,54 & 6,19 \\
\hline Potatoes & 0 & 0 & 0 & 0 & 0 & 0 \\
\hline Other Tubes & 24,54 & 7,50 & 24,54 & 1,94 & 0,58 & 1,94 \\
\hline Total & 1265,38 & 1292,52 & 1265,38 & 100,00 & 100,00 & 100,00 \\
\hline
\end{tabular}

Source: Primary Data, 2017.

Table 3. Level of Participation in Consumption of Animal Protein Food Sources in the Border Area

\begin{tabular}{|c|c|c|c|c|c|c|}
\hline \multirow[t]{2}{*}{ Type of Food } & \multicolumn{3}{|c|}{ Food Quantity kkal/kap/hr } & \multicolumn{3}{|c|}{ Energy Contribution (\%) } \\
\hline & Local & Transmigrant & Local+Transmigarn & Local & Transmigrant & Local+Transmigrant \\
\hline Fish & 117,55 & 83,66 & 92,27 & 56,19 & 57,65 & 53,56 \\
\hline Meat & 53,70 & 8,79 & 32,98 & 25,67 & 6,06 & 19,14 \\
\hline Poutry Meat & 20,62 & 25,73 & 24,28 & 9,85 & 17,73 & 14,09 \\
\hline Eggs & 17,34 & 26,94 & 21,08 & 8,29 & 18,57 & 12,24 \\
\hline Milk & 0,00 & 0,00 & 1,68 & 0,00 & 0,00 & 0,97 \\
\hline Total & 154 & 145,12 & 172,29 & & & \\
\hline
\end{tabular}

Source: Primary Data, 2017.

Table 4. Level of Participation in Consumption of Vegetable Protein Food Sources in the Border Area

\begin{tabular}{|c|c|c|c|c|c|c|}
\hline \multirow[t]{2}{*}{ Type of Food } & \multicolumn{3}{|c|}{ Food Quantity kkal/kap/hr } & \multicolumn{3}{|c|}{ Energy Contribution $(\%)$} \\
\hline & Local & Transmigrant & Local+Transmigrant & Local & Tranmisgrant & Local+Transmigrant \\
\hline Peanuts & 0,00 & 0 & 0,00 & 0,00 & 0 & 0,00 \\
\hline Soybeans & 37,60 & 111,06 & 71,77 & 100,00 & 92,52 & 94,74 \\
\hline Green Beans & 0,00 & 8,98 & 3,98 & 0,00 & 7,48 & 5,26 \\
\hline Other Beans & 0,00 & 0,00 & 0,00 & 0,00 & 0,00 & 0,00 \\
\hline Total & 37,60 & 120,04 & 75,75 & & & \\
\hline
\end{tabular}

Source: Primary Data, 2017.

Table 5. Levels of Participation in Consumption of Fat Food Source in the Border Area

\begin{tabular}{lccccc}
\hline Type of Food & \multicolumn{2}{c}{ Food Quantity kkal/kap/hr } & \multicolumn{2}{c}{ Energy Contribution (\%) } \\
\hline Coconut Oil & Local & Transmigrant & Local+Transmigran & Local & Transmigran \\
Palm Oil & 51,06 & 6,80 & 40,52 & 39,09 & 3,64 \\
Other Types of Oil & 77,20 & 177,56 & 127,51 & 59,10 & 95,13 \\
Coconut & 0,00 & 0,00 & 0,00 & 0,00 & 0,00 \\
Candlenut & 2,36 & 2,29 & 4,26 & 1,81 & 1,23 \\
Total & 0,00 & 0,00 & 0,00 & 0,00 & 0,00 \\
\end{tabular}

Source: Primary Data, 2017.

Table 6. Level of Participation in Food Consumption of Vitamins and Minerals Source of Farmers Households in the Border area

\begin{tabular}{lccccc}
\hline Type of Food & \multicolumn{3}{c}{ Food Quantity kkal/kap/hr } & \multicolumn{2}{c}{ Energy Contribution (\%) } \\
\hline Vegetables & Local & Transmigrant & Local+Transmigrant & Local & Transmigration \\
Fruits & 69,17 & 64,87 & 72,82 & 61,83 & 60,32 \\
Total & 42,70 & 42,68 & 46,31 & 38,17 & 39,68 \\
\hline
\end{tabular}

Source: Primary Data. 2017. 
Table 7. Average Energy Consumption of Protein Food Sources of Household Farmers in the Border Area

\begin{tabular}{lcc}
\hline Description & Average Per Capita Consumption/Day \\
\hline & Energy (kkal/kap/day) & \%AKE \\
Local & $1.774,29$ & 82,53 \\
Transmigrant & $1.856,77$ & 83,49 \\
Border area & $1.815,53$ & 84,44 \\
\hline
\end{tabular}

Source: Primary Data, 2017.
Table 8. Average Protein Consumption of Farmers' Households in the Border Area

\begin{tabular}{lcc}
\hline Description & \multicolumn{1}{c}{ Average Per Capita Consumption/Day } \\
\hline & Protein $(\mathrm{g} /$ kap/day) & $\% \mathrm{AKP}$ \\
Local & 47,59 & 83,49 \\
Transmigrant & 52,46 & 92,04 \\
Border Area & 50,02 & 87,76 \\
\hline
\end{tabular}

Source: Primary Data. 2017.

Table 9. Calorie Distribution and Desirable Dietary Pattern Score (PPH) of Farmers' Households in the Border Area

\begin{tabular}{|c|c|c|c|c|c|c|}
\hline \multirow[t]{2}{*}{ Food Group } & \multicolumn{3}{|c|}{ Calorie Distribution } & \multicolumn{3}{|c|}{ PPH Score } \\
\hline & $\begin{array}{c}\text { Local } \\
\text { Household } \\
\end{array}$ & $\begin{array}{c}\text { Transmigrant } \\
\text { Household }\end{array}$ & $\begin{array}{c}\text { Border Area } \\
\text { Household }\end{array}$ & $\begin{array}{c}\text { Local } \\
\text { Household } \\
\end{array}$ & $\begin{array}{c}\text { Transmigrant } \\
\text { Household }\end{array}$ & $\begin{array}{c}\text { Border Area } \\
\text { Household }\end{array}$ \\
\hline Grains & 841,91 & 1146,58 & 974,64 & 19,58 & 25,00 & 22,67 \\
\hline Tubers & 432,59 & 145,94 & 290,74 & 2,50 & 2,50 & 2,50 \\
\hline Animal Food & 209,21 & 145,12 & 172,29 & 19,46 & 13,50 & 16,03 \\
\hline Oil and Fat & 128,26 & 184,36 & 168,03 & 2,98 & 4,29 & 3,91 \\
\hline Fruit/Oily Seeds & 2,36 & 2,29 & 4,26 & 0,05 & 0,05 & 0,10 \\
\hline Nuts & 37,60 & 120,04 & 75,75 & 3,50 & 10,00 & 7,05 \\
\hline Sugar & 3,85 & 19,75 & 7,43 & 0,09 & 0,46 & 0,17 \\
\hline Vegetables and & 111,87 & 107,55 & 119,12 & 26,02 & 25,01 & 27,70 \\
\hline \multicolumn{7}{|l|}{ Fruit } \\
\hline Others & 0,21 & 0,00 & 0,10 & 0,00 & 0,00 & 0,00 \\
\hline Total & 1767,86 & 1871,64 & 1812,38 & 74,18 & 80,81 & 80,12 \\
\hline
\end{tabular}

Source:Primary Data, 2017.

Table 10. Independent Sample Test for Household Food Consumption of Farmers in the Papua Border Area

\begin{tabular}{|c|c|c|c|c|c|c|c|c|}
\hline & & \multicolumn{2}{|c|}{$\begin{array}{c}\text { Levene's Test for } \\
\text { Equality of Variances }\end{array}$} & \multicolumn{3}{|c|}{ t-test for Equality of Means } & \multirow{2}{*}{$\begin{array}{c}\text { Mean } \\
\text { Difference }\end{array}$} & \multirow{2}{*}{$\begin{array}{l}\text { Std. Error } \\
\text { Difference }\end{array}$} \\
\hline & & F & Sig. & $\mathrm{t}$ & $\mathrm{df}$ & Sig. (2-tailed) & & \\
\hline \multirow[t]{2}{*}{$\mathrm{KE}$} & Equal variances assumed & 0.000 & 0.990 & -0.766 & 158 & 0.445 & -26.420 & 34.469 \\
\hline & Equal variances not assumed & & & -0.766 & 157.474 & 0.445 & -26.420 & 34.469 \\
\hline \multirow[t]{2}{*}{ KP } & Equal variances assumed & 0.032 & 0.858 & 0.622 & 158 & 0.535 & 1.232 & 1.981 \\
\hline & Equal variances not assumed & & & 0.622 & 157.514 & 0.535 & 1.232 & 1.981 \\
\hline
\end{tabular}

Description: KE: Energy Consumption KP: Protein Consumption.

\section{Discussion}

The analysis shows that the type of carbohydrate food source consumed by farmers' households in the border area consists of rice, cassava, sweet potato, and sago. Table 1 shows that rice is the staple food that has the highest contribution to carbohydrate consumption of farm households $(74.4 \%)$. The same results were obtained by [17], in that the consumption of grains accounted for a large portion $(44.54 \%)$ of the total calories consumed by households in eastern Indonesia. [18] also stated that the energy adequacy of carbohydrate food sources by $50 \%$ came from the cereal food group. Similarly, the research by [13], pointed out that the contribution of rice dominates the consumption of food in Java. In addition to Java, rice consumption also dominates in Kalimantan, for example on Sebatik Island [12]. The consumption of rice by farmer households in the border area is around $91.9 \mathrm{~kg} / \mathrm{capita} /$ year. This consumption amount is slightly lower than the national rice consumption in 2017 as revealed by [19] amounting to $97.6 \mathrm{~kg} /$ capita/year.

The high level of participation in rice consumption in the Papua border area is related to the staple food pattern of farmers in the border area who greatly depend on rice as the main food source. By comparing the result between local farmer households and transmigrant farmers, it is revealed that the rice contribution in meeting the carbohydrate needs of transmigrant farmer households is greater than that of local farmer households. This is greatly attributed to the main farming activities carried out by transmigrant farmers, namely rice farming, especially lowland rice. The amount of production set aside for household consumption ranges from $10-20 \%$ of production. In addition, transmigrant farmer households mostly originate from Java Island, which has always greatly depended on rice as the main staple food from generation to generation. On the contrary, local farmer households generally do not cultivate rice in their farming. However, it turns out that rice is also a staple food for this household, although the contribution of rice in the food consumption of local farmer households is smaller than that of transmigrant farmer households. The level of participation of rice for food consumption of local farmers' households is higher than other types of food. This shows that rice has become a staple food source for local farmers / Papuan people. This is in line with [20], finding that all respondent households in Tablanusu Village, Depapre District, Jayapura Regency consume rice, with the highest consumption frequency (83.1 times/month on average) of all other energy-based food sources. The results of [21] study also obtained the same results, initially the food of the community in Kampung Makimi Nabire Papua was sweet potatoes, cassava and sago, but now it has shifted to rice. The same thing in the shifting of people's food patterns also occurred 
in Maluku, initially consuming sago as a staple food, currently switching to rice, as stated in the research [22]. Not only in Indonesia, even in the world rice /cereal has an important role in people's food consumption. According to [23] said that Cereals continue to remain by far the most important food source in the world, contributing 50 per cent of calories and as much as 54 per cent in developing countries. Their contribution to energy intake varies markedly between developing and industrial countries. In developing countries such as in Africa and parts of Asia, cereals can contribute as much as 70 per cent of energy intake.

The local farmer households in the border area obtain their rice from the market and also from the government ("Raskin", Rice for the Poor). The farmer households received the Raskin of $15 \mathrm{~kg} / \mathrm{month} /$ family. [17] suggested that Raskin has a considerable contribution to the food consumption of people in the Eastern part of Indonesia.

Other Carbohydrate food sources than rice consumed by farmers are cassava, sweet potato, and sago, with the highest proportion being sweet potatoes. The local farmers will mostly consume these carbohydrate food sources as a substitute for rice in case of rice shortage. However, sometimes, they also consume these food sources together with rice if they have an insufficient amount of rice available. In contrast, transmigrant farmers only consume cassava and sweet potatoes for snacks or variations from the regular staple food, while sago is consumed only at certain times if desired or for a celebration. Most local farmers decide to consume other carbohydrate food sources than rice because they cultivate cassava, sweet potato, and sago as the dominant commodity. In addition, the food commodity has been the staple food for the local farmers, as it has been passed down from generation to generation. Sweet potatoes are also a source of food for people in Africa [24,25,26,27]. However, now this culture has started to dwindle because the local farmers in Papua have shifted their food consumption patterns to consuming rice.

Table 3 shows that the consumption of food sources of animal protein in the border area consists of fish, ruminant meat, poultry meat, and eggs. The highest level of participation in animal protein food source comes from fish, which is the same as the result revealed by [13]. The farmer households mostly consume both fresh fish and canned fish. Fresh fish is consumed more by transmigrant farmer households, while salted / dried fish and canned fish is consumed more by local farmer households. The fresh fish species consumed by farmers are mostly derived from marine fish. This trend is triggered by the fact that some local farmers who live in the city of Jayapura also work as fishermen as their side job. Besides, transmigrant farmers find it relatively easier to obtain marine fish because their resident is relatively closer to the sea and the provincial capital. In addition to fresh fish derived from the sea, they also consume fresh fish obtained from freshwater. In Muara Tami Regency, there are many transmigrant farmer households who cultivate freshwater fish, such as tilapia, parrot fish, and catfish.

The next animal protein food source is ruminant meat, with the largest proportion coming from meat consumption by local farmer households. Many local farmers consume pork and deer as ruminant meat. Usually, to obtain animal protein food source, the local farmers hunt some animals in the forest, resulting in quite high consumption of meat. [28] say that hunting is performed in order to supply a family consumption with complete meals. Deer and wild pig are killed in primary forest. In addition to fish and meat, animal protein food source are also obtained from poultry and eggs. Mostly they rely on broiler chicken and locally bred chicken. [29] say that chicken serves as an alternate source of protein especially for lower and middle income group.

Table 4 shows that vegetable protein sources of farmer households in the border area come from soybeans. This finding is in line with the research by [13] on food selfsufficient villages in Java. Soybean food is obtained from tofu and tempeh consumption since both of them are relatively cheap ( \pm Rp. 5,000/fruit) and affordable for farmers. In addition, tofu and tempeh are easy to obtain because they are available in the market, especially in transmigrant areas.

Fat will function as an energy source for the body and is the body's largest energy reserve. One gram of fat produces nine calories [30], 2.25 times greater than the energy obtained from one gram of carbohydrate and protein. The fats in food provide a savory and delicious taste. [31] stated that the source of visible fat was obtained from the extraction of animal and vegetable foods, such as cooking oil, butter, margarine, and shortening. Hidden fat is not obviously visible fat that is present in daily food consumption, such as fat in meat, milk, eggs, and avocados.

The level of participation in the consumption of fat food sources by farmer households in the border area is presented in the following table. Based on Table 5, it is apparent that farmer households in the border area have the highest level of participation in fat food sources derived from palm oil. Palm oil is more frequently used by farmers to fry or saute food than coconut oil. By comparing local farmer households and transmigrant farmers, it appears that the transmigrant farmer household use palm oil more frequently, while coconut oil is more widely used by local farmers. The local farmers have better use of coconut because coconut is easily available in the garden and is more affordable because they can make it on their own without having to purchase it in the market.

Other foods that are important to the body are food sources of vitamins and minerals such as fruits and vegetables. The group of vegetable foods mostly consumed by farmers in the border area is water spinach, spinach, mustard greens, cassava leaves, and sweet potato leaves. Meanwhile, the fruits most frequently consumed by farmers are bananas, papaya, and oranges. Many farmers were known to consume oranges during the research observation because there was a harvesting time in Keerom Regency at that time. The level of participation in the consumption of vitamin and mineral food sources is presented in the following table.

Table 6 shows that vegetables have the largest contribution in meeting the needs of the vitamins and minerals of farmer household in the border area. The contribution of vegetables in meeting the needs of vitamins and minerals amounted to $61.8 \%$. Vegetable consumption by transmigrant farmer households is higher than the consumption of local farmer households. This shows that farmers' awareness of the importance of consuming vitamins and minerals food source is quite high. 
In addition, the availability of fertile land that makes it suitable for vegetable crops planting makes many farmers cultivate vegetables in their farming. Most transmigrant farmers use a quarter of their land to grow vegetables. Vegetable crops grown by farmers are primarily intended for sale, but some parts are provided for self-consumption. This condition allows the sufficient availability of vegetables so that the consumption of vegetable in every household farmers is fulfilled. For local farmers, vegetables are the main food supplement in addition to rice since many of whom cannot afford to buy other dishes due to the low level of income and scarce availability of food.

The results showed that the average Energy Adequacy Rate (AKE) in the border area was still below the AKE indicator consumed according to Widyakarya National Food and Nutrition X in 2012, which amounted to 2,150 calories/capita/day. Farmers' households in the border area only meet the AKE of around $81.20 \%$ of the recommended AKE, with an average of 1747.60 calories/capita/day. By comparing local farmer households and transmigrant farmer households, it is obvious that transmigrant farmer households have $0.20 \%$ greater percentage of AKE than that of local farmer households. This condition is related to the variation and quality of food consumed by transmigrant farmers, which is apparent from the contribution of the distribution of calories consumed by farmer households as in Table 7.

Table 8 shows that transmigrant farmer households have a greater AKP than the local AKP of local farmer households. This condition is attributed to the fact that transmigrant farmers consume more various protein food sources than those consumed by local farmer households. Apart from the various protein food source, transmigrant farmers also have better sufficiency of available protein food source in their residential areas, because they live relatively closer to the market. However, the AKP value for both local farmers and transmigrants is still below the standard protein sufficiency of $57 \mathrm{~g} / \mathrm{capita} /$ day. Therefore, it is vital to enhance their protein consumption through some programs for farmers in the border area, such as through "gemar makan ikan" (being fond of eating fish).

The calculation of total AKP scores of farmer households in the border area amounted to $77.5 \%$. According to classification, it falls into a sufficient category. By comparing between the households of local farmers and transmigrant farmers, the total score of AKP for transmigrant houses is higher than that of the local farmer households, but both are still in the sufficient category. The AKP score, which is still in this sufficient category, is mainly due to the gap in the AKE score and the maximum score for the 8 food groups where the animal food is the highest contributor of -8.9. This shows that the consumption of animal food by farmer households in the border region is still below the standard. One of the reasons is attributed to the relatively expensive price of animal food. The average price of 1 kilogram of beef is Rp. 145,000 and the price of 1 chicken are Rp. 40,000 Rp. 60,000, while chicken eggs cost Rp. 2,000/item.

Table 9 shows that transmigrant farmer households have higher calorie distribution and higher PPH scores than that of local farmer households. Based on food consumption according to food groups, grain has the highest calorie distribution and PPH score, which happens because the households of both local farmers and transmigrants use food groups of grains as a staple food source. For local farmer households, high-calorie distribution is also found in tubers. This is attributed to the fact that besides food consumption of food groups of grains as a staple food, local farmers also consume tubers food as a staple food in case of rice shortage.

Table 10 shows that the significance value of Leven's test is greater than $\alpha: 0.05$ for both energy consumption and protein consumption. This means that the data is homogeneous or there is no difference in variance between data. Therefore, the next interpretation shall use equal variances assumed. It can be seen that the significance value for energy consumption and protein consumption is greater than $\alpha$ : 0.05 , with each significance value of 0.474 and 0.329 . This means that the null hypothesis $(\mathrm{H} 0)$ is rejected, meaning that significantly the average energy consumption and protein consumption of local farmer household is different from the average energy consumption and protein consumption of transmigrant farmer household in the Papua border area.

\section{Conclusions}

The average energy consumption of farmer households in the border area is 1749.37 calories/capita/day, or only meets the AKE of around $81.37 \%$ of the recommended AKE of 2150 calories/capita/day. Meanwhile, the protein consumption is still at 47.90 calories/capita/day or $84.03 \%$ of the recommended AKP of 57 calories/capita/day. By comparing local farmer households and transmigrant farmer household, it is revealed that the household energy consumption of local farmers is greater than the energy consumption of transmigrant farmer households. On the contrary, the protein consumption of local farmer household is lower than the protein consumption of transmigrant farmer household. The results of the analysis of two independent t-test sample showed that the average energy consumption and protein consumption of local farmer households differed significantly from the average energy consumption and protein consumption of transmigrant farmer household in the Papua border area.

\section{References}

[1] Ma Guansheng. "Food Eating Behavior and Culture in Chinese", Society. Journal of Ethnic Foods, 2(4), 195-199, 2015.

[2] Azetsop, J., T. R. Joy. Acces to Nutritious Food, Socioeconomic, Individualism and Public Health Ethics in The USA: A Common Good Approach. Philosophy, Ethics and Humanities in Medicine, 8(6), 1-13, 2013.

[3] R. Ruben, J. Verhagen, and C. Plaisier. "The Challenge of Food Systems Research: What Difference Does It Make?", Sustainability, 2019(11), 2019.

[4] Saputi, R., L.A. Lestari and J. Susilo. Pola Konsumsi Pangan dan Tingkat Ketahanan Pangan Rumah Tangga di Kabupaten Kampar Provinsi Riau. Jurnal Gizi Klinik Indonesia, 12(3), 123-130, 2016.

[5] Gezer Ceren. Impact of Dietary Pattern on Human Life Quality and Life Expectancy: A Mini-Review. Research and Investigation Sport Medicine, 2(5), 1-4, 2018.

[6] WHO. Nutrition for Health and Development.A Global Agenda for Combating Malnutrition. Progress Report. WHO, Nutrition for Health and Development (NHD) and Sustainable Development and Health Environments (SDE). 2000. 
[7] Cahyaningsih, R. Analisis Pola Konsumsi Pangan di Provinsi Jawa Barat. Skripsi. Institut Pertanian Bogor. 2008.

[8] Turua U., S. Hadi, B. Juanda, and E. Murniningtyas. "Ekologi dan Budaya Petani Asli Papua Dalam Usahatani Di Kabupaten Keerom", Sosiohumaniora, 16(3), 112014.

[9] B.P.S. Provinsi Papua Dalam Angka. BPS Provinsi. Jayapura, Papua, 2015.

[10] Pasifik Pos.Com. SDA Papua Dapat Diandalkan Untuk Ketahanan Pangan. Published on September 17th 2015. 2015.

[11] Maxwell Frankenberg. "Household Food Security: Concepts, Indicators, and Measurement. A Technical Review", 1992.

[12] Mulyo J.H., Irham, Jumeri, A.H. Widodo, G. Wirakusuma \& H. Perwitasari. Food Security of Farm Households in Indonesia's Border Area, Sebatik Island. International Journal of Engineering and Technology, 7(3.30), 314-319, 2018.

[13] Dirhamsyah, T., J.H. Mulyo, D. H. Darwanto, S. Hartono. Kemandirian Pangan dan Kesejahteraan Masyarakat Daerah Rawan Pangan di Jawa. Plantaxia, 2016.

[14] Supriana T., T.C. Pane. The Influence of Consumer Characteristics on The Amount of Rice Consumption. IOP Conference Series: Earth and Environmental Science, 122(2018).

[15] Mole J. Ary. The Role of Indigenous People. 2016. Downloaded on January 7.

[16] Hardinsyah Pertiwi and Ekawidyani. "Konsumsi Pangan Dan Gizi Serta Skor Pola Pangan Harapan (Pph) Pada Anak Usia Sekolah 7-12 Tahun Di Indonesia. Jurnal Gizi dan Pangan”, Juli, 2014(9), 117-124, 2014. ISSN 1978-1059.

[17] Rachmaningsih T., Priyarsono, D.S. "Ketahanan Pangan di Kawasan Timur Indonesia. Jurnal Ekonomi dan Pembangunan Indonesia", Vol, 13(1), 1-18, 2012.

[18] Apriani S., Baliwati Y.F. Faktor-faktor yang berpengaruh terhadap Konsumsi Pangan Sumber Karbohidrat di Pedesaan dan Perkotaan, Jurnal Gizi, volume 3, 2011.

[19] Arifin B., N. A. Achsani, D. Martianto, L. K. Sari, and A. H Firdaus. Modeling The Future of Indonesian Food Consumption Final report. Research Report submitted to the National Development Planning Agency (Bappenas), World Food Programme (WFP) and Food and Agricultural Organization of the United. Nations (FAO), 2018.

[20] Wasaraka Yulia N. K. Pola Konsumsi Pangan Masyarakat Papua (Studi Kasus di Kampung Tablanusu, Distrik Depapre, Kabupataen Jayapura, Provinsi Papua). Skripsi. Institut Pertanian, Bogor. Bogor, 2011.

[21] Baransano, R., I.W. Windia, and I.D.P.O. Suardi. Dampak Perubahan Pola Konsumsi Pangan Lokal Ubi dan Sagu menjadi Pangan Beras di Kampung Makimi, Distrik Makimi, Kabupaten
Nabire, Provinsi Papua. E-Jurnal Agribisnis dan Agrowisata, vol 8(2), 262-271, 2019.

[22] Pattiselanno A.E., J.F. Sopamena. The Change of Local Food Consumption Pattern From Sago to Rice (Case Study of Social Change in Central Maluku). International Journal of Current Research and Academic Review, vol 5(4), 17-23, 2017.

[23] Kearney, J. Food Consumption Trends and Drivers. Philosophical Transaction of The Royal Society, B 365(2010), 2793-2807, 2010.

[24] Miyazaki, H., Y. Ishimoto, V. Tanaka and C. Umetsu. The Role of The Sweet Potato in The Crop Diversification of Small-Scale Farmers in Southern Province, Zambia. Africa Study Monographs, vol 34(2), 119-137, 2013.

[25] Sakala, P., E. Kunneke and M. Faber. Household Consumption of Orange -Fleshed Sweet Potato and Its Associated Factors in Chipata District, Eastern Province Zambia. Food and Nutrition Bulletin, vol 39(1), 127-136. 2018.

[26] Mukras, M.S., O.J. Alphonce and G. Momanyi. Determinants of Demand for Sweet Potatoes at The Farm, Retail and Wholesale Markets in Kenya Advances in Economics and Business, vol 1(2), 150-158. 2013.

[27] Aboajah, F.N., Ejechi M.E., Viashima S.S., Adeyongu S.K., and Muogbo P.C. Sweet Potato Production for Poverty Alleviation in Nasarawa State, Nigeria. International Journal of Environment, Agriculture and Biotechnology vol 3(2), 380-387, 2018.

[28] Pattiselanno F., M.I. Lubis. Hunting at The Abun Regional Marine Protected Areas: A Link Between Wildmeat and Food Security. HAYATI Journal of Bioscience, vol 21(4), 180-186, 2014.

[29] Arifin B., N. A. Achsani, D. Martianto, L. K. Sari, and A. H. Firdaus. Modeling The Future of Indonesian Food Consumption Final report. Research Report submitted to the National Development Planning Agency (Bappenas), World Food Programme (WFP) and Food and Agricultural Organization of the United. Nations (FAO), 2018.

[30] Atmojo, I. R.W. "Ilmu Gizi”, 2010. Retrieved on March $5^{\text {th }}$.

[31] Widiyanto. Metode Pengukuran Berat Badan. Jurnal Medikora, vol 1(2), 105-118, 2005.

[32] Arifin B., N. A. Achsani, D. Martianto, L. K. Sari, and A. H. Firdaus. Modeling The Future of Indonesian Food Consumption Final report. Research Report submitted to the National Development Planning Agency (Bappenas), World Food Programme (WFP) and Food and Agricultural Organization of the United. Nations (FAO),2018.

[33] Wasaraka Yulia N. K. Pola Konsumsi Pangan Masyarakat Papua (Studi Kasus di Kampung Tablanusu, Distrik Depapre, Kabupataen Jayapura, Provinsi Papua). Skripsi. Institut Pertanian, Bogor. Bogor, 2011.

[34] Atmojo Idam R.W. "Ilmu Gizi”, 2010. Retrieved on March 5th.

C The Author(s) 2019. This article is an open access article distributed under the terms and conditions of the Creative Commons Attribution (CC BY) license (http://creativecommons.org/licenses/by/4.0/). 